\title{
Morpho-anatomical adaptation of the leaves of certain Veronica species to arid conditions
}

\author{
D) Olena Leshcheniuk ${ }^{1}$, (1) Tetyana Chipilyak ${ }^{2}$ \\ 1 Institute of Evolutionary Ecology, National Academy of Sciences of Ukraine, Lebedeva str. 37, 03143 Kyiv, Ukraine; \\ fedorova8@bigmir.net \\ ${ }^{2}$ Kryvyi Rih Botanical Garden, National Academy of Sciences of Ukraine, Marshak str. 50, 50089 Krivyi Rih, Ukraine; chipiljak@i.ua
}

Received: 22.07 .2020 | Accepted: 09.09.2020 | Published: 30.12 .2020

\begin{abstract}
This study's objective was to evaluate the adaptive potential of the leaves of Veronica ( $V$. austriaca, $V$. incana, and V. prostrata) in the arid conditions of the Kryvyi Rih Botanical Garden NAS of Ukraine (KBG) located in the Right-Bank Steppe Cisdnieper. Leaves have been obtained from the collection of ornamental plants of KBG, where these plants are introduced for ten years. The seasonal dynamics of leaf development have been studied during the growing season of 2018, when the most arid climatic conditions were observed.

The leaves of the investigated species were found to be dorsoventral, amphistomatic, with an anomocytic stomatal apparatus and bifacial mesophyll. Changes in the anatomical structures of the leaf blade towards xeromorphism were determined. In particular, in all studied specimens thickening of the cuticle, adaxial and abaxial epidermises (except $V$. prostrata, where the upper epidermis decreased by $35 \%$ ) mesophyll occurred. The number of stomata on the abaxial epidermis in all species decreased (the most notably in $V$. prostrata). Such increase of xeromorphism in $V$. austriaca, $V$. incana, and $V$. prostrata is an adaptive reaction of plants to the effects of extreme arid weather and climatic conditions of the Kryvorizhzhya, which testifies to the plasticity of investigated species and their high adaptation potential to the climatic conditions of the Right-Bank Steppe Cisdnieper.
\end{abstract}

Keywords: Veronica, anatomy, leaf, plasticity, drought resistance

\section{Introduction}

In the conditions of increasing technogenic pressure in Ukraine and global climate warming, it is necessary to search for new drought- and pollution-resistant species for purposes of ornamental planting. According to the long-term introductory observations of the Veronica L. representatives in the collection of the Kryvyi Rih Botanical Garden of the NAS of Ukraine (KBG), five species (V. armenica Boiss., V. austriaca L., V. incana L., V. prostrata L., and V. spicata L.) were identified as promising to replenish the cultural flora of the Right-Bank Steppe Cisdnieper. These species occur in different conditions in the wild nature. They came from Circumboreal, Irano-Turanian, and Eastern Asiatic floristic regions (Yelenevskiy, 1978; Takhtajan, 1978; Kotov et al., 1999). In ornamental gardening, these unpretentious plants are appreciated for the extraordinary beautiful flowers, long-blooming, various shapes and color of leaves, and high resistance to diseases and pests. Unfortunately, in the Kryvyi Rih plantings, these species are not used due to insufficient information regarding their ecological preferences and biological characteristics (Chypylyak et al., 2014).

Investigations of the morphological and anatomical structure of the plant organs, 

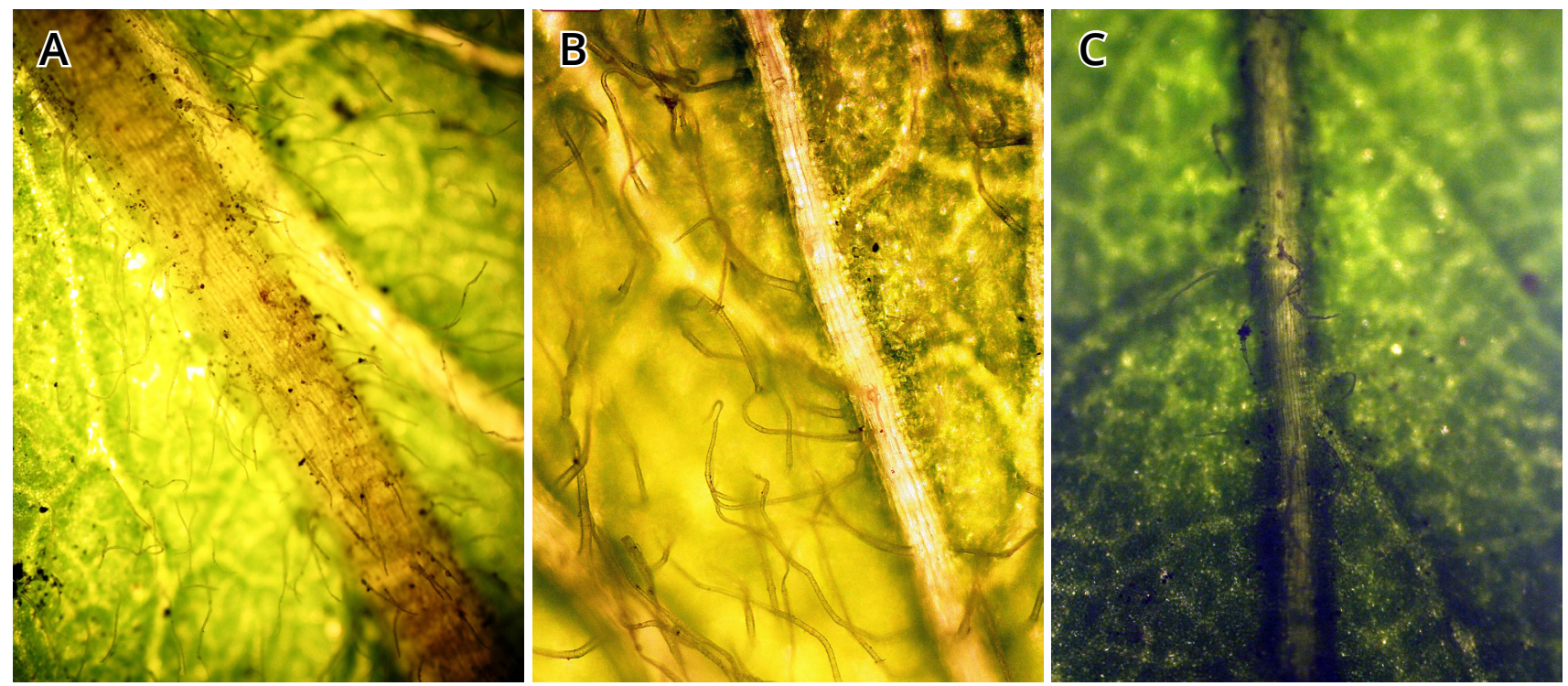

Figure 1. Trichomes of Veroniva austriaca (A), V. incana (B), and V. prostrata (C) leaves (×4).

particularly the leaves (as the most labile to the influence of environmental factors), are principal for determination of the species' adaptive capacity (Grodzinskiy, 2013; Shvets, 2013).

Some morpho-anatomical studies of Veronica from different growth areas were performed to standard medicinal raw materials (Kaplan et al., 2007; Marchyshyn et al., 2015; Mocan et al., 2015; Antsyshkina et al., 2017). However, information on the anatomic and morphological structure of Veronica leaves in the context of adaptive plasticity to the conditions of the Right-Bank Steppe Cisdnieper is absent.

Three Veronica species (V. austriaca, $\mathrm{V}$. incana, and V. prostrata) with different biomorphological and decorative features (Leshcheniuk, 2017, 2018, 2019) that were introduced at the KBG for over ten years were selected for the current research. Under the introduction conditions, V. incana and V. prostrata belong to the hamephytes, and V. austriaca to hemicryptophytes (Raunkiaer, 1907). All species are herbaceous polycarpics (Serebryakov, 1964).

\section{Material and methods}

The research was conducted in KBG during the growing season of 2018. That year was characterized by the extreme weatherclimatic conditions. The leaves were selected twice during the growing season - in the first ten-day period of June during the completion of the spring regrowth phase (summer sampling), and in the third ten-day period of September at the beginning of completion of vegetative development (autumn sampling). Sampling in the autumn was preceded by high temperature during June-August (from 32.5 to $35.3^{\circ} \mathrm{C}$ ) and the lack of precipitation for a long time. During summer of 2018, only $71.6 \mathrm{~mm}$ of precipitations fell, which is twice less than the usual precipitation $(160 \mathrm{~mm})$ during this period in Kryvyi Rih.

We used temporary slides made from mature leaves to study their anatomical and morphological structure. Median leaves formation of 15 plants per each species was used (Vekhov et al., 1980; Barykina et al., 2004). Cross-sections were prepared by hand with a razor on the level of a third of the leaf's length. The slides were examined with Carl Zeiss Primo Star microscope at $\times 10, \times 20$, and $\times 40$ magnifications. The leaf, epidermis, and mesophyll thickness was measured at the same distance from the edge of the leaf and the main vein. The number of stomata was counted per the field of view. Stomatal apparatus has been classified following Baranova (1985). General morphological characteristics of the leaves were provided following Zyman et al. (2004). Measurements were performed in the AxioVision 4.8.2 environment. Data were statistically processed through the dispersal analysis, according to Dospekhov (1985) using MS Excel 2003. 

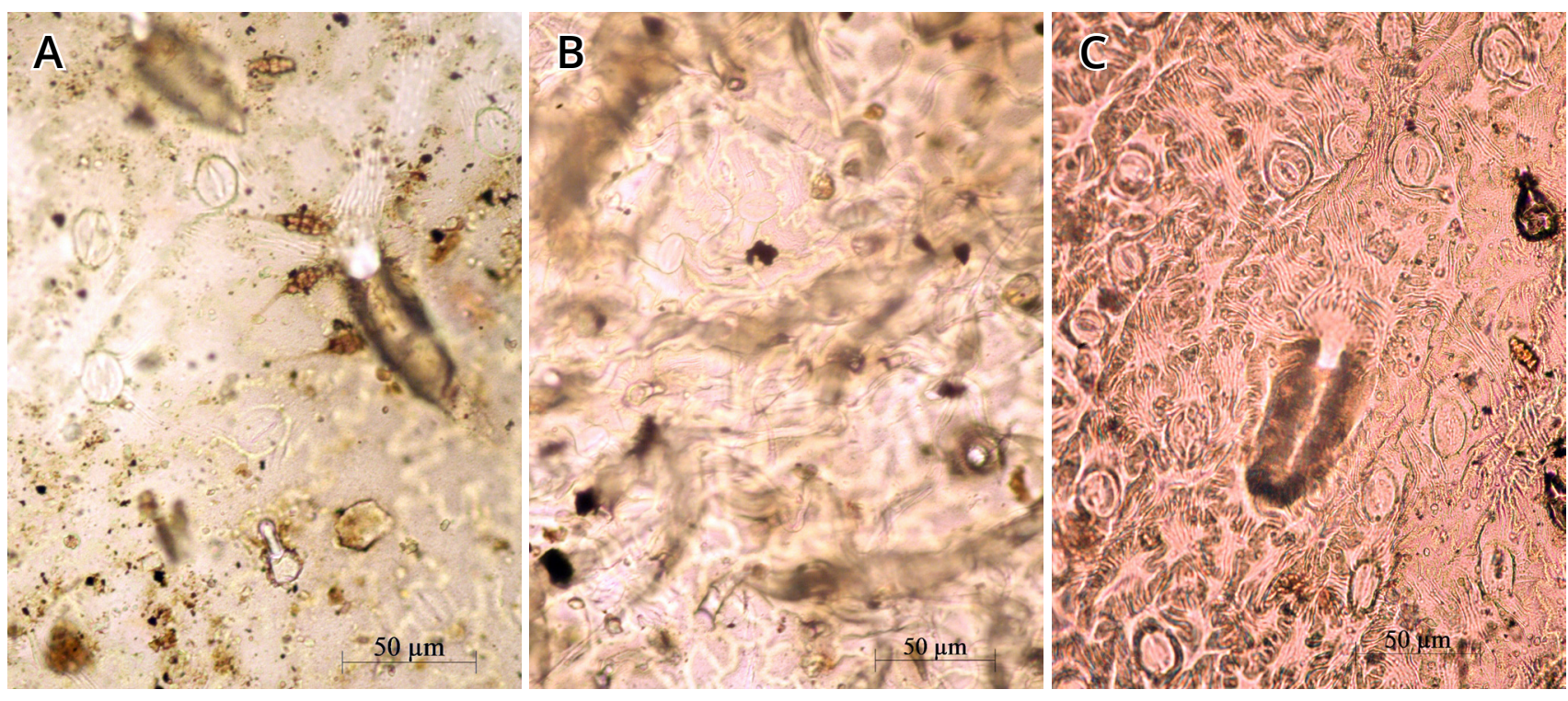

Figure 2. Aadaxial epidermis of Veroniva austriaca (A), V. incana (B), and V. prostrata (C) leaves.

The introduction area (Kryvorizhzhya) is located in the southwest of the Dnipropetrovsk region, in the Steppe natural zone. It belongs to Ukraine's arid regions (Kazakov et al., 2005), where the average precipitation is 425-450 $\mathrm{mm}$ per year (with a maximum in early summer). The rest of the summer is characterized by prolonged droughts, high anomalous temperatures, and little or absent precipitations. In the warm period, dry winds are observed. The winter has harsh climatic conditions with icing, water stagnation on the soil surface, and frequent thaws followed by short but low freezing temperatures $\left(-27--30^{\circ} \mathrm{C}\right)$. Due to global warming in recent decades, some meteorological indicators have changed in the Kryvorizhzhya (Kazakov et al., 2005; Rp5, 2020). The average annual temperature increased from $+8.5^{\circ} \mathrm{C}$ in 1987 to $+10.0-+11.5^{\circ} \mathrm{C}$ in $2014-2018$. The average daily temperature in JanuaryFebruary increased from $-5.1--4.4^{\circ} \mathrm{C}$ in 1987 to $-1.7--1.5^{\circ} \mathrm{C}$ in 2018 . The average daily temperature of the hottest months, July and August, also increased from $+22-+21^{\circ} \mathrm{C}$ in 1987 to $+23.5-+24.8^{\circ} \mathrm{C}$ in 2018 . In the summer, there are prolonged droughts in the presence of anomalously high temperatures (+36.7 $+38.1^{\circ} \mathrm{C}$ ). In general, the climatic conditions of 2018 were hot and extreme for growing plants. The increased temperatures were observed from May (daytime temperature reached $+32.5-+33.3^{\circ} \mathrm{C}$ ) till September (with temperature maximum of $+35.3^{\circ} \mathrm{C}$ ). The annual precipitation in 2018 was only $364 \mathrm{~mm}$. Only a few rains felled from April to October, which led to prolonged air and soil drought during the vegetation period.

\section{Results and discussion}

The leaves of the middle formation of V. austriaca have ovate or ovate-oblong leaf blade, with a wedge-shaped or rounded base, with a toothed margin and a pointed tip, $3.7 \pm 0.2 \mathrm{~cm}$ long, and $1.7 \pm 0.2 \mathrm{~cm}$ wide. The leaf blade of V. incana is lanceolate, smalltoothed, $5.9 \pm 0.9 \mathrm{~cm}$ long, and $1.8 \pm 0.2 \mathrm{~cm}$ wide. The leaf blade of $\mathrm{V}$. prostrata is oblonglanceolate or linear-lanceolate, with a wedgeshaped base, crenate margin, and obtuse apex, $2.2 \pm 0.4 \mathrm{~cm}$ long, and $0.5 \pm 0.1 \mathrm{~cm}$ wide.

The leaf blade of all studied species is dorsoventral. The leaves' upper and lower surfaces are covered by single- and multicellular covering trichomes, at the base of which two or three-celled rosettes are located. In $\mathrm{V}$. austriaca there are also four-celled rosettes at the base of trichomes. The longest covering trichomes having sharp tips are bent to the leaf surface. The highest number of trichomes has been observed in V. incana (Fig. 1). In all investigated species, besides covering trichomes, there are also glandular hairs. In V. prostrata they are clavate, with a unicellular elongated stem and bicellular head.

The leaves' upper and lower epidermises consist of a single layer of cells with highly convoluted walls. The adaxial epidermis cells, 


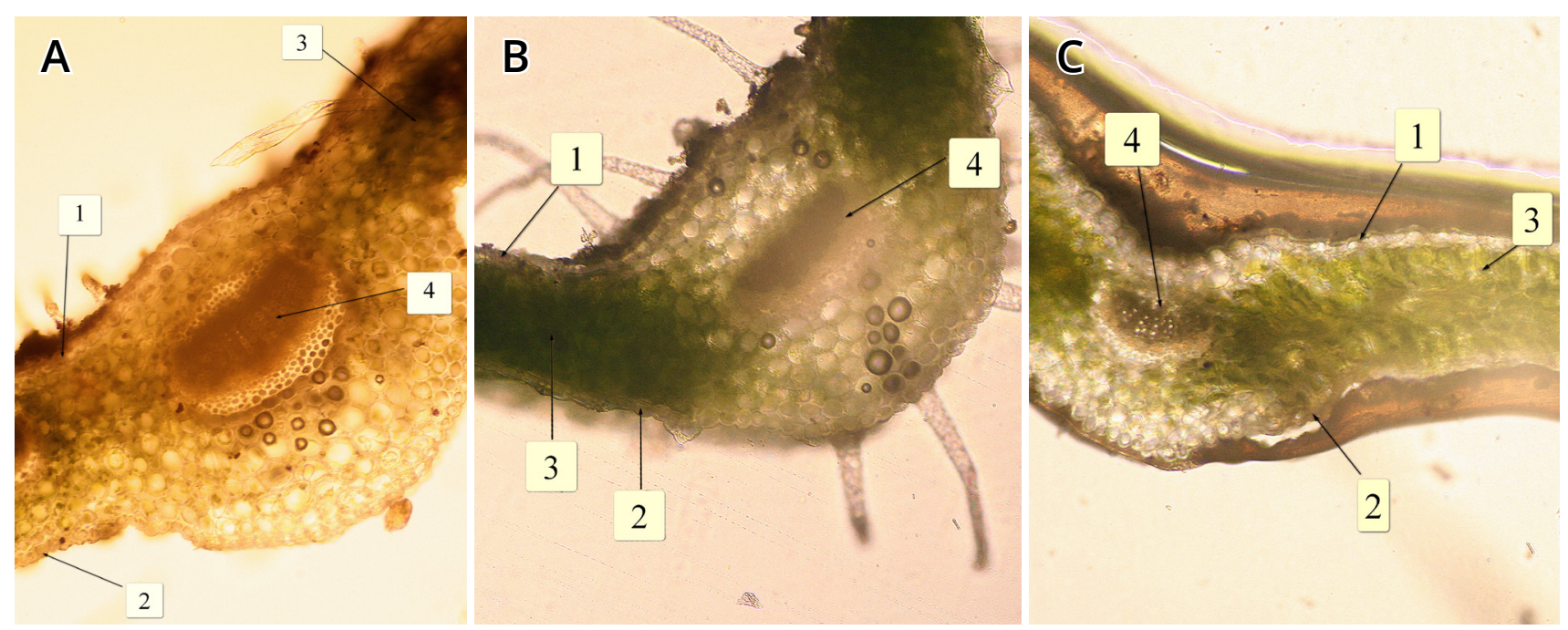

Figure 3. Cross-section of Veronica leaf blade in the central vein area: A - V. austriaca; $\mathbf{B}-V$. incana; C V. prostrata (×20). 1 - adaxial epidermis; 2 - abaxial epidermis; 3 - mesophyll; 4 - central vein.

which are covered with a cristate cuticle, are smaller than those located on the abaxial surface (almost $50 \%$ in the $\mathrm{V}$. austriaca, and V. incana and $21 \%$ - in the V. prostrata) (Table 1; Fig. 2). The leaves of the investigated species are amphistomatic, usual for xerophytes and mesophytes that grow in arid conditions (Vasilevskaya, 1965). The stomata of the anomocytic type, oval or spherical-oval, granose, located randomly on the adaxial and abaxial sides of the leaf blade on the same level as other epidermal cells. Same as other epidermal cells, stomata are also smaller on the adaxial surface of the leaf blade.

The mesophyll is bifacial. Palisade parenchyma, which consists of 2-3 layers of elongated cells, is located under the upper epidermis.

Below the palisade cells, a two- or threelayered spongy parenchyma is formed by ovate cells, which are located loosely in early summer and more densely in the autumn. Among the mesophyll cells, idioblasts with calcium oxalate raphides are scattered. Such raphides have a protective function and help to scatter light, which protects plants against excessive insolation and overheating (Nakata, 2003; Franceschi \& Nakata, 2005; López-Macías et al., 2019). Open collateral vascular bundles are accompanied by the parenchymatic lining (Fig. 3).

Due to the temperature stress and prolonged air-soil drought in 2018, quantitative and functional changes in the leaf blade's anatomical structures of investigated plants occurred. V. austriaca has undergone the slightest changes compared to other species. The thickness of the leaf blade in V. austriaca from the beginning of summer to the end of September increased by $8 \%$, and mesophyll - by $6 \%$. The thickness of the cuticle and the adaxial epidermis in V. austriaca increased the most (by 12 and $11 \%$, respectively). At the same time, the thickness of the abaxial epidermis in this species increased only by $5 \%$. The size of stomata on the adaxial surface during the growing season did not change significantly. However, the size of the stomata on the abaxial surface decreased by $8 \%$. The number of stomata did not change significantly (Table 1).

Among the investigated species, the most significant thickening of the cuticle $(40 \%)$, adaxial (60\%), and abaxial (27\%) epidermises was recorded in $\mathrm{V}$. incana plants (Table 1). The thickness of the leaf blade and mesophyll increased by $20 \%$. By the end of the growing season, palisade mesophyll obtained a more compact structure. The size of stomata on the adaxial surface increased by $8 \%$. However, the stomata on the abaxial side became much smaller by $13 \%$. The number of stomata on the abaxial epidermis simultaneously decreased by $38 \%$.

Veronica prostrata demonstrated certain features of adaptation to the prolonged hot and dry period. At the beginning of summer, the mesophyll in this species had no clear distinction between palisade and spongiform parenchymas and was represented by loosely placed cells. However, at the end of the 
Table 1. Morphometric parameters of the leaf blade in the investigated Veronica species.

\begin{tabular}{|c|c|c|c|c|c|c|c|}
\hline \multirow{2}{*}{ Parameters } & \multirow{2}{*}{$\begin{array}{l}\text { Sampling } \\
\text { time }\end{array}$} & \multicolumn{2}{|c|}{ V. austriaca } & \multicolumn{2}{|c|}{ V. incana } & \multicolumn{2}{|c|}{ V. prostrata } \\
\hline & & $\mathrm{M} \pm \mathrm{m}$ & $\mathrm{CV}, \%$ & $\mathrm{M} \pm \mathrm{m}$ & $\mathrm{CV}, \%$ & $\mathrm{M} \pm \mathrm{m}$ & $\mathrm{CV}, \%$ \\
\hline \multirow{2}{*}{$\begin{array}{l}\text { The thickness of the leaf } \\
\text { blade, } \mu \mathrm{m}\end{array}$} & summer & $184.5 \pm 5.0$ & 12.3 & $203.1 \pm 3.7$ & 9.1 & $284.0 \pm 5.7$ & 10.6 \\
\hline & autumn & $200.9 \pm 7.3$ & 18.2 & $245.3 \pm 3.6$ & 7.4 & $385.3 \pm 9.7$ & 12.6 \\
\hline \multirow[t]{2}{*}{ Cuticle thickness, $\mu \mathrm{m}$} & summer & $4.8 \pm 0.5$ & 25.4 & $3.9 \pm 0.2$ & 22.3 & $7.5 \pm 0.3$ & 20.7 \\
\hline & autumn & $5.4 \pm 0.2$ & 21.5 & $5.4 \pm 0.3$ & 20.1 & $8.1 \pm 0.6$ & 22.6 \\
\hline \multirow{2}{*}{$\begin{array}{l}\text { The thickness of adaxial } \\
\text { epidermis, } \mu \mathrm{m}\end{array}$} & summer & $8.9 \pm 0.8$ & 15.4 & $9.0 \pm 0.3$ & 15.3 & $18.5 \pm 0.8$ & 20.9 \\
\hline & autumn & $10.4 \pm 0.3$ & 12.3 & $14.4 \pm 0.6$ & 21.2 & $11.7 \pm 0.3$ & 11.4 \\
\hline \multirow{2}{*}{$\begin{array}{l}\text { The thickness of abaxial } \\
\text { epidermis, } \mu \mathrm{m}\end{array}$} & summer & $16.8 \pm 0.9$ & 15 & $17.3 \pm 0.6$ & 17.1 & $23.3 \pm 0.7$ & 14.8 \\
\hline & autumn & $17.6 \pm 0.6$ & 13.4 & $22.0 \pm 0.6$ & 12.9 & $23.1 \pm 0.3$ & 6.1 \\
\hline \multirow{2}{*}{$\begin{array}{l}\text { The thickness of the } \\
\text { mesophyll, } \mu \mathrm{m}\end{array}$} & summer & $131.3 \pm 1.9$ & 7.1 & $146.9 \pm 2.3$ & 7.9 & $199.6 \pm 4.1$ & 10.3 \\
\hline & autumn & $139.7 \pm 3.3$ & 11.9 & $172.0 \pm 2.3$ & 6.7 & $278.4 \pm 9.6$ & 17.3 \\
\hline \multirow{2}{*}{$\begin{array}{l}\text { Sizes of stomata on adaxial } \\
\text { surface (length / width), } \\
\mu \mathrm{m}\end{array}$} & summer & $\begin{array}{l}28.8 \pm 0.7 / \\
19.7 \pm 0.8\end{array}$ & 11.4 / 9.6 & $\begin{array}{l}24.9 \pm 0.4 / \\
20.3 \pm 0.3\end{array}$ & $8.7 / 6.7$ & $\begin{array}{l}26.9 \pm 0.2 / \\
25.8 \pm 0.3\end{array}$ & $9.5 / 11.4$ \\
\hline & autumn & $\begin{array}{l}29.7 \pm 0.5 / \\
20.1 \pm 0.4\end{array}$ & $9.6 / 7.6$ & $\begin{array}{l}27.2 \pm 0.1 / \\
21.8 \pm 0.4\end{array}$ & $5.7 / 7.9$ & $\begin{array}{l}26.3 \pm 0.9 / \\
24.1 \pm 0.1\end{array}$ & $11.7 / 9.9$ \\
\hline \multirow{2}{*}{$\begin{array}{l}\text { Sizes of stomata on abaxial } \\
\text { surface (length / width), } \\
\mu \mathrm{m}\end{array}$} & summer & $\begin{array}{l}30.8 \pm 0.7 / \\
21.9 \pm 0.5\end{array}$ & $13.5 / 9.6$ & $\begin{array}{l}27.5 \pm 0.5 / \\
17.6 \pm 0.5\end{array}$ & $11.3 / 11.2$ & $\begin{array}{l}29.8 \pm 0.5 / \\
22.2 \pm 0.6\end{array}$ & $8.5 / 13.8$ \\
\hline & autumn & $\begin{array}{l}28.4 \pm 0.5 / \\
22.4 \pm 0.4\end{array}$ & $9.6 / 8.5$ & $\begin{array}{l}23.9 \pm 0.2 / \\
17.1 \pm 0.4\end{array}$ & $5.1 / 10.8$ & $\begin{array}{l}24.3 \pm 0.7 / \\
18.1 \pm 0.4\end{array}$ & $13.6 / 11.9$ \\
\hline
\end{tabular}

Note. summer - first ten days of June; autumn - last ten days of September; $\mathbf{M} \pm \mathbf{m}$ - the arithmetic mean and standard deviation; CV - coefficient of variation.

growing season, the mesophyll had a clear differentiation into 2-3-layered palisade parenchyma with elongated, tightly arranged, cylindrical cells and 2-3-layered spongy parenchyma constructed by roundish cells. The thickness of the mesophyll and the leaf blade in general increased by $35 \%$ (Table 1), which is the most notable among the studied species. The cuticle in V. prostrata thickened only by $8 \%$, but its size was the largest among the species studied both in early summer and autumn - 7.5 and $8.1 \mu \mathrm{m}$, respectively. The adaxial epidermis, unlikely to other species, became $35 \%$ thinner. The number of stomata decreased by $77 \%$, their size on the adaxial surface - decreased by $7 \%$, and on the abaxial surface - by $18 \%$. We believe that such changes in the anatomical structure of leaf blade are an adaptive response of plants to the effects of hot and dry conditions and contribute to the regulation of gas exchange, protection of plants from overheating and excessive transpiration (Esau, 1969).

\section{Conclusions}

The leaves' anatomical and morphological features may indicate adaptation of V. austriaca, V. incana, V. prostrata species to the arid climate of Kryvorizhzhya. In all investigated species, the increase of xeromorphic features (thickening of the leaf blade, mesophyll, cuticle, and epidermis, as well as changes of the stomatal indices and the arrangement of mesophyll cells) has been observed.

The most significant changes in the anatomical structure of the leaf were observed in V. prostrata. Veronica incana was characterized by the most numerous trichomes and the most significant thickening of the cuticle, adaxial and abaxial epidermis. The slightest changes in the anatomical structure of the leaf blade were observed in V. austriaca plants. The revealed changes in the leaf structure of the investigated Veronica species can be considered an adaptive response of plants to the effects of extreme 
arid climatic conditions. This indicates the plasticity of the investigated Veronica species and their adaptation potential to the conditions of the Right-Bank Steppe Cisdnieper.

\section{References}

Antsyshkina, A. M., Morokhina, S. L., \& Plyashnik, N. V. (2017). Morphological and anatomical study of some European species of the genus Veronica. Journal of Pharmacy, 66(3), 20-23. (In Russian)

Baranova, M. A. (1985). Classifications of the morphological types of stomata. Botanicheskiy Zhurnal, 70(12), 1585-1595. (In Russian)

Barykina, R. P., Veselova, T. D., Devyatov, A. G., Dzhalilova, K. K., Ilina, G. M., \& Chubatova, N. V. (2004). Handbook of botanical microtechniques. Basics and methods. Moscow: Moscow State University. (In Russian)

Chypylyak, T. F., Mazura, M. Yu., Bereslavska, O. O., \& Leshcheniuk, O. M. (2014). Flower design of parks and squares in the city of Kryvyi Rih: Condition, problems and recommendations for improvement. Scientific Bulletin of NLTU of Ukraine, 24(4) 164-169. (In Ukrainian)

Dospekhov, B. A. (1985). Field experimental technique (with the basics of statistical processing of research results). Moscow: Agropromizdat. (In Russian)

Esau, K. (1969). Plant anatomy. Moscow: World. (In Russian)

Franceschi V. R., \& Nakata, P. A. (2005). Calcium oxalate in plants: Formation and function. Annual Review of Plant Biology, 56, 41-71. https://doi.org/10.1146/annurev. arplant.56.032604.144106

Grodzinskiy, D. M. (2013). Adaptive strategy of physiological processes of plants. Kyiv: Naukova Dumka. (In Ukrainian)

Kaplan, A., Hasanoglu, A., \& Ince, I. A. (2007). Morphological, anatomical and palynological properties of some Turkish Veronica L. species (Scrphulariaceae). International Journal of Botany, 3(1), 23-32. https://doi.org: 10.3923/ ijb.2007.23.32

Kazakov, V. L, Paran'ko, I. S., Smetana, M. H., Shypunova, V. O., Kotsyuruba, V. V., \& Kalinichenko, O. O. (2005). Natural geography of Kryvbas. Kryvyy Rih: KDPU. (In Ukrainian)

Kotov, M. I., Prokudin, Y. N., \& Barbarich, A. I. (1999). The determinant of higher plants of Ukraine. Kiev: Phytosociocenter. (In Russian)
Leshcheniuk, O. M. (2017, March 1-2). Ecological and biological features of Veronica incana $\mathrm{L}$. during introduction into the Kriviy Rig Botanical Garden of the NAS of Ukraine (Steppe zone). In Plants and Urbanization (pp. 101-103). Dnipro. (In Ukrainian)

Leshcheniuk, O. M. (2018, March 3). Seasonal rhythm of development of Veronica austriaca $\mathrm{L}$. in the conditions of Kryvorizhzhya. In Plants and Urbanization (pp. 86-88). Dnipro. (In Ukrainian)

Leshcheniuk, O. M. (2019, May 22-24). Ecological and biological features of Veronica prostrata $\mathrm{L}$. and prospects of its use in the conditions of the Right-Bank Steppe Dnieper. In Introduction and conservation of plant diversity in the botanical gardens of Eastern Europe (pp. 45-46). Kyiv. (In Ukrainian)

López-Macías, B., Morales-Martínez, S., LozaCornejo, S., Reyes C., Terrazas, T., Patakfalvi, R., Ortiz-Morales, M., \& Miranda-Beltrán, M. (2019). Variability and composition of calcium oxalate crystals in embryos-seedlings-adult plants of the globose cacti Mammillaria uncinata. Micron, 125, 102731. https://doi.org/10.1016/j. micron.2019.102731

Marchyshyn, S. M., Sira, L. M., \& Milyan, I. I. (2015). Morphological-anatomical structure of the Veronica prostrata L. grass. Ukrainian Biopharmaceutical Journal, 3, 78-82. (In Ukrainian)

Mocan, A., Vodnar, D., Vlase, L., Crisan, O., Gheldiu, A.-M., \& Crisan, G. (2015). Phytochemical characterization of Veronica officinalis L., V. teucrium L. and V. orchidea Crantz from Romania and their antioxidant and antimicrobial properties. International Journal of Molecular Sciences, 16(9), 21109-21127. https:// doi.org/10.3390/ijms160921109

Nakata, P. (2003). Advances in our understanding of calcium oxalate crystal formation and function in plants. Plant Science, 164(6), 901-909. https:// doi.org/10.1016/S0168-9452(03)00120-1

Raunkiaer, C. (1907). Planterigets Livsformes of deres Betydning for Geografies. Kobenhavn: Nordiskforlag.

Rp5. (2020). The weather site. Retrieved from http:// rp5.ua/

Serebryakov, I. G. (1964). Life forms of plants and studying of them. In Field geobotany. Vol. 3 (pp. 146205). Moscow - Leningrad: Nauka. (In Russian)

Shvets, I. V. (2013). Composition and distribution of species of the genus veronica (Veronica L.) on the territory of Kyiv and Kyiv region. Biological Systems: Theory and Innovation (Ukrainian version), 193, 38-44. (In Ukrainian). Retrieved from http:// journals.nubip.edu.ua/index.php/Biologiya/ article/download/637/611 
Takhtajan, A. L. (1978). Floristic regions of the world. Leningrad: Nauka. (In Russian)

Vasilevskaya, V. K. (1965). Structural adaptations of hot and cold deserts of Middle Asia and Kazakhstan. Problems of Modern Botany, 2, 5-17. (In Russian)

Vekhov, V. N., Lotova, L. I., \& Filin, V. R. (1980). Workshop on the anatomy and morphology of higher plants. Moscow: MSU. (In Russian)
Yelenevskiy, A. G. (1978). Systematics and geography of veronics of the USSR and the neighboring countries. Moscow: Nauka. (In Russian)

Zyman, S. M., Mosyakin, S. L., Bulakh, O. V., Tsarenko, O. M., \& Fel'baba-Klushyna, L. M. (2004). Illustrated guideto themorphologyofflowering plants. Uzhhorod: Medium. (In Ukrainian)

\section{Морфо-анатомічна адаптація листків окремих видів Veronica до посушливих умов}

Олена Лещенюк ${ }^{1}$, Тетяна Чипиляк ${ }^{2}$

1 Інститут еволюційної екології НАН України, вул. Лебедєва, 37, Київ, 03143, Україна; fedorova8@bigmir.net

2 Криворізький ботанічний сад НАН України, вул. Маршака, 50, Кривий Ріг, 50089, Україна; chipiljak@i.ua

3 метою визначення адаптаційного потенціалу досліджено морфо-анатомічну структуру листка трьох видів роду Veronica ( $V$. austriaca, $V$. incana та $V$. prostrata) за умов вирощування у Криворізькому ботанічному саду НАН України (КБС), що розташований у кліматичних умовах Правобережного степового Придніпров'я. Матеріал отримали з колекційного фонду квітниково-декоративних рослин КБС, де згадані види інтродуковано впродовж десяти років. Сезонну динаміку вивчали протягом вегетаційного періоду 2018 року, який характеризувався найпосушливішими умовами.

Виявлено, що рослини досліджуваних видів добре пристосовані до зростання в посушливих і спекотних умовах, про що свідчать ксероморфні риси анатомічної будови листків, зокрема: розвинуті опушення та кутикула, рафіди оксалату кальцію, амфістоматичний тип листкової пластинки, а також диференційований мезофіл. Виявлено, що в умовах дефіциту вологи та за високої температури у рослин $V$. austriaca, $V$. incana та $V$. prostrata відбувалося посилення ознак ксероморфності, а саме: потовщення шару кутикули й обидвох епідермісів (за винятком $V$. prostrata), зменшення розмірів продихів та їхньої кількості на нижньому епідермісі листкової пластинки, ущільнення клітин палісадного та губчастого мезофілів. Такі кількісні й якісні зміни структури листкової пластинки можна розглядати як пристосувальну реакцію рослин на дію екстремальних посушливих погоднокліматичних умов, що свідчить про пластичність досліджених видів та їхній високий адаптаційний потенціал в умовах Правобережного степового Придніпров'я. 